\title{
DAMPAK REFORMA AGRARIA DARI BAWAH TERHADAP KESEJAHTERAAN MASYARAKAT DI DESA GARONGAN DAERAH ISTIMEWA YOGYAKARTA
}

\author{
Valentina Sokoastri*) dan Endriatmo Soetarto \\ Departemen Sains Komunikasi dan Pengembangan Masyarakat, Fakultas Ekologis Manusia, IPB \\ *)Email: valentinasokoastri@yahoo.com
}

\begin{abstract}
Agrarian reform by leverage or commonly known as landreform by leverage is a peasant movements which is organized by peasant initiative to defend their land. This movement could be associated with social welfare and negative excess like criminalization that frequently take place in Garongan village. There, most people involved in conflict because of their persistence to keep their land. There is a strong relationship between agrarian reform by leverage and peasant welfare. Land which is frequently referred as crucial donation of life has a vital value for human survival. The function of land is not only considered as human needs but also as identity that always triggers any conflict nowadays. So, it's not strange if this condition causes any negative impacts of criminalization including psychological, physical or both psychological and physical effects for those who involved. At the end of this description, farmers who have been sovereign from agriculture will be interferred by iron sand mining company which is supported by feudal forces and private corporations. This research examine more deeply about the relationship between agrarian reform by leverage and social welfare, the impact of agrarian reform by leverage to the criminalization and the differences of level of social welfare before and after agrarian reform in Garongan village.
\end{abstract}

Keywords: agrarian reform by leverage, criminalization, social welfare.

\section{PENDAHULUAN}

Kajian tentang petani mensyaratkan dilakukannya penelusuran terhadap kebijakan pemerintah Indonesia. Analisis politik dan kebijakan menunjukkan bahwa selama 32 tahun terakhir, negara menggunakan topdown approach dalam merespon persoalan-persoalan pembangunan, termasuk bidang pertanian. Program pembangunan pertanian yang dikembangkan menghasilkan strategi besar (grand strategy) yang menjauhkan petani dari persoalan nyata. Revolusi hijau, misalnya hanya merespon sebagian kecil masalah petani sehingga mewujud pada upaya melayani kepentingan elit tertentu tanpa melihat konteks permasalahan petani. Kondisi demikian menyebabkan petani harus dihadapkan dengan tekanan permasalahan sebagai efek revolusi hijau misalnya persoalan ekologis, akses terhadap sumberdaya, kesenjangan, kesetaraan peran laki-laki dan perempuan, dll.

Upaya menjawab permasalahan tersebut dilakukan dengan mengembangkan bentuk pendekatan pembangunan yang melibatkan partisipasi petani. Program yang dikembangkan lebih berbasis lokal dimana penanggung jawab program bersama petani menganalisis kebutuhan-kebutuhan petani di tingkat lokal. Konsep yang kemudian muncul adalah pemberdayaan dan partisipasi yang didesain bagi keterlibatan petani. Paradigma ini lebih dikenal sebagai community development (CD) dengan ciri bottom up approach.

Perkembangan selanjutnya menunjukkan pendekatan model CD yang berkembang tidak betul-betul menyentuh akar permasalahan petani. Kajian CD tidak menganalisis lebih lanjut misalnya tentang ketergantungan yang dihadapi petani terhadap faktor luar. Sejauh ini, CD tidak lebih dari upaya mengukuhkan proses integrasi petani kedalam formasi kapitalis. Pernyataan tersebut didukung oleh Hickey dan Mohan bahwa CD masa kolonial maupun post-kolonial dimaksudkan untuk menjaga kestabilan komunitas pedesaan dan digunakan untuk menghambat gerakan petani, dalam upaya mempertahankan hegemoni negara (Hickey \& Mohan, 2005). Implikasi dari tidak tersentuhnya akar persoalan petani ${ }^{1}$ adalah persoalan tidak pernah diselesaikan dengan tuntas. Hal ini membutuhkan respon tersendiri dari petani. Upaya merespon permasalahan dapat dimulai dengan membangun kemandirian petani. Penelitian ini memaparkan usaha membangun bentuk-bentuk kemandirian petani dalam hal ekonomi, tata cara produksi dan pengelolaan sumber-sumber agraria. Kemandirian tingkat lokal menduduki peran penting

\footnotetext{
${ }^{1}$ Selain permasalahan petani tidak tersentuh, pekerja yang berada di bawah paradigma community development seringkali tidak menganggap sesuatu sebagai masalah. Implikasinya, banyak dimensi persoalan petani yang menjadi laten dan sewaktu-waktu bisa manifest.
} 
terutama jika dikaitkan dengan keinginan menghindari intervensi kapitalis sekaligus memutus relasi kekuasaan dominan.

Perkembangan mutakhir menunjukkan, respon mulai diwujudkan dalam bentuk organisasi petani. Kemandirian petani dapat didekati melalui pembentukan organisasi sebagai sebuah kelembagaan. Berangkat dari pernyataan di atas, tampaknya pengorganisasian petani dalam berbagai bentuk menjadi sebuah keharusan untuk mengantarkan petani pada posisi yang lebih setara dalam sebuah struktur sosial. Dengan demikian, dalam upaya memperkuat posisi petani, pembentukan organisasi petani menjadi penting dikaji.

Tipe organisasi yang dibangun merupakan respon terhadap pendekatan pengorganisasian komunitas desa yang selama ini dilakukan oleh pemerintah. Pemerintah menciptakan bangunan organisasi dengan menerapkan prinsip-prinsip topdown yang tidak berpihak pada petani. Disamping itu, organisasi petani dapat dikatakan merupakan perlawanan atas paradigma pembangunan pertanian yang selama ini dipilih pemerintah. Keterhubungan antara permasalahan petani dan pilihan tipe organisasi didekati dengan cara melihat karakter organisasi yang dibangun pada masa reformasi. Secara sengaja, penelitian ini akan difokuskan pada organisasi yang dibangun atas dasar motivasi ekonomi dan produksi untuk memperoleh gambaran karakter perlawanan organisasi tersebut. Menarik mengkaji tipe organisasi produksi yang menggunakan pendekatan community development yang dipahami dalam kerangka perlawanan petani.

Pertanyaan umum penelitian dalam hal ini diarahkan pada bagaimana respon petani atas permasalahan sosio-ekonomi dan politik yang dihadapi sebagai implikasi paradigma pembangunan pertanian. Sedangkan, secara khusus pertanyaan penelitian yang ada sebagai berikut:

1. Bagaimana, mengapa dan dalam kondisi apakah organisasi petani terbentuk sebagai respon atas permasalahan ekonomi dan politik?

2. Karakter pengorganisasian petani bagaimana yang berpeluang memberikan solusi atas permasalahan yang ada?

3. Bagaimana karakter perlawanan petani apabila dikaitkan dengan watak negara dan aktor global?

\section{Tujuan dan Kegunaan Penelitian}

Penelitian ini dimaksudkan untuk menghasilkan studi tentang bentuk-bentuk respon petani atas permasalahan sosio-ekonomi dan politik yang dihadapi. Analisis sejarah dimaksudkan untuk memahami konteks ekonomi dan politik dibalik pembentukan organisasi yang menjadi kendala petani berorganisasi, disamping sebagai pendorong pembentukan organisasi petani. Melalui gambaran tersebut, dapat dipahami proses dinamika petani pada komunitasnya ketika dihadapkan pada kepentingan supra lokal, bahkan kepentingan global. Pemahaman karakter organisasi petani menjadi dasar menganalisis karakter perlawanan petani dalam merespon situasi/permasalahan yang ada.

Penelitian ini berguna untuk memberikan kesadaran tentang masalah-masalah yang muncul dibalik "kesuksesan" pembangunan pada masa orde baru. Bentuk-bentuk pendekatan pemerintah terhadap komunitas ditinjau secara kritis. Ditinjau dari sisi praxis, penelitian ini menjadi penting untuk melihat sejauh mana organisasi petani memainkan perannya dalam membangun kesejahteraan anggota dan komunitasnya. Dalam konteks pemberdayaan lokal, studi ini memberi warna lain bagi pemegang kebijakan bahwa inisiatif lokal harus dibangun dan diberikan keleluasaan berkembang, sekaligus memberi kontribusi bagi terbentuknya pengelolaan sumber daya alam yang berkeadilan.

\section{PENDEKATAN TEORITIS}

\section{Tinjauan Pustaka}

\section{Petani: Sebuah Entitas Sosial Khas}

Perdebatan tentang pertautan petani dalam relasi antar subyek membawa kembali pada sudut pandang sosiologi. Kajian sosiologis menempatkan petani sebagai bagian dari struktur masyarakat yang lebih besar. Sumbangan Scott (1993) tentang relasi sosial yang dibangun petani dengan aktor lain melahirkan prinsip "safety first" untuk menyelamatkan diri dari kekuatan lain.

Kritik Popkin (1986) terhadap Scott menyatakan bahwa petani memiliki apek-aspek rasionalitas untuk menunjang kelangsungan kehidupan mereka. Selama masih ada tingkat-tingkat ekonomi ganda, keinginan untuk maju dari satu tingkat ke tingkat selanjutnya, dan keinginan untuk menghindari kejatuhan, para petani akan selalu terlibat baik dalam asuransi maupun dalam perjudian yakni investasi yang aman atau penuh resiko. Meskipun secara teoritis paparan Popkin merupakan kritik atas tesis Scott, namun prakteknya, masih terdapat prinsip 'mencari aman' yang muncul dalam investasi yang dijalankan dimana petani cenderung akan memilih investasi pribadi untuk kesejahteraan masa depan melalui anak dan tabungan daripada berinvestasi, dan mengandalkan resiprositas dan asuransi masa depan yang berasal dari desa.

Lain halnya dengan Pearse (1968) yang melahirkan respon aktif petani untuk mempertahankan keterlibatan dengan dunia luar. Keterhubungan petani dengan struktur ekonomi yang lebih besar berimplikasi pada adaptasi yang bermuara pada perubahan karakter petani. Keterlibatan petani dengan kapitalisme mendorong petani melakukan perubahan orientasi ekonomi yang cenderung mengedepankan aspek rasionalitas. Terkait dengan hal tersebut kemudian muncul konsep depeasantisasi dimana petani 
terintegrasi kedalam sistem ekonomi kapitalis sehingga ada perubahan pola kultural dan struktural.

Pendekatan dimensi perubahan sosial dalam meninjau perkembangan karakter dan orientasi petani dalam tatanan sosial yang lebih kompleks diungkapkan oleh Migdal (1974). Migdal melakukan pendekatan kajian tersebut dari dimensi perubahan sosial. Perubahan sosial dan ekonomi diintegrasikan kedalam teori tentang partisipasi petani dalam politik dan revolusi. Tulisan Migdal memaparkan dengan gamblang karakter dari keterlibatan petani dalam ruang politik. Inisiatif keterlibatan petani dalam arena politik lebih banyak diinisiasi oleh non-petani. Dengan demikian keterlibatan petani dalam arena yang lebih besar belum berasal dari inisiatif lokal.

Gambaran tersebut didukung oleh tulisan Friedmann (1992) tentang peasant dalam konteks sistem ekonomi global. Tulisan tersebut memudahkan melihat keterkaitan petani dengan sistem ekonomi dunia. Ketika petani terintegrasi dalam ekonomi, pada saat itu ciri-ciri kehidupan petani dalam berbagai segi akan mengadaptasikan diri sedemikian rupa sehingga perubahan-perubahan yang muncul akan terkait dengan sistem ekonomi dan juga budaya. Keterlibatan petani dengan kapitalisme memberikan pengaruh kepada petani terutama dalam hal perubahan orientasi produksi, penyesuaian strategi hidup yang dilakukan serta berubahnya nilai-nilai hidup yang dianut.

Meski secara gamblang dipaparkan perjalanan petani hingga sampai pada keterkaitan dengan sistem ekonomi global, namun petani tetap menjadi entitas yang termarjinalkan. Fenomena demikian sesungguhnya menunjukkan bahwa petani masih berada dalam kerangka kungkungan struktural. Kondisi demikian didefinisikan oleh Soetomo (1997) sebagai kekalahan petani. $^{2}$ Kesadaran bahwa kemiskinan petani tercipta akibat tekanan struktural mulai menguat sejak konstelasi politik berubah dari represif menjadi terbuka. Periode ini ditandai sejak turunnya Soeharto pada tahun 1998. Iklim reformasi membuka celah terbentuknya organisasi petani dengan dukungan perubahan orientasi yang lebih mengarah pada political community.

Gerakan Sosial: Sejarah, Perkembangan dan Mekanisme

Harper (1989) memahami gerakan sosial sebagai kolektifitas-kolektifitas yang tidak konvensional

\footnotetext{
2 Soetomo (1997) mengungkapkan bahwa kekalahan petani disebabkan oleh dua faktor; pertama, faktor alam (natural resource). Dalam hal ini mengemuka sebuah diskusi tentang perbedaan karakter yang tercipta yang muncul akibat perbedaan konteks ekologis, antara dataran tinggi dan dataran rendah. Jika dikaitkan dengan pengorganisasian, jelas terdapat hubungan antara keduanya. Kedua, faktor struktural. Terbentuknya kemiskinan struktural dipandang sebagai akibat yang dipengaruhi oleh beberapa hal yaitu: a) petani kecil merupakan kelompok marjinal karena keikutsertaannya dalam sistem sosial telah meletakkan mereka sebagai elemen yang dibuat bergantung tak berdaya sepenuhnya; b) pilihan-pilihan petani ditentukan oleh pihak-pihak diluar petani; c) petani terasing dari jaringan-jaringan informasi aktual mengingat keterbatasan kemampuan kognitif mereka, sistem transportasi yang belum sempurna, dan perbedaan kultur serta posisi inferior.
}

dengan berbagai tingkatan organisasi yang berusaha mendorong maupun mencegah perubahan. Asal perubahan dikemukakan oleh Sztompka (1994) berasal dari bawah. Sebagai gerakan manifes dari bawah, gerakan sosial ini dicirikan oleh bersatunya orang-orang untuk mengorganisir diri dalam tujuannya membuat perubahan dalam masyarakat. Dalam perubahan sosial, gerakan sosial bisa menjadi penyebab, efek maupun mediator yang mempengaruhi jalannya perubahan sosial.

Kajian Fauzi (2005) tentang gerakan rakyat di beberapa Negara Dunia Ketiga berhasil memotret bentuk-bentuk karakter perlawanan. Perlawanan dimulai dengan konfrontasi terhadap dominasi pemerintah, pengusaha, atau penguasa. Strategi yang dikembangkan adalah mobilisasi rakyat, bahkan kasus Indonesia menunjukkan gerakan rakyat dilakukan dengan cara mengkonstruksi kembali identitas etnis. Buku tersebut memprofilkan dinamika ringkas masing-masing gerakan, terutama dalam 3 (tiga) pokok utama yang membingkai gerakan masing-masing, yakni (i) tafsir atas situasi yang dimusuhi, (ii) kesempatan politik yang memungkinkan para aktor gerakan menetapkan pilihanpilihan strategis; dan (iii) pilihan jenis aksi kolektif yang diandalkan para pelaku gerakan (Fauzi, 2005: 7-8).

Selain Fauzi (2005), tulisan Fakih (2000) juga mencoba menggambarkan perlawanan terhadap pemerintah dengan melihat keterkaitan antara arus besar model pembangunan dengan tumbuhnya gerakan sosial. Meski kajian keduanya menyandarkan pada kasus LSM - bukan organisasi petani - sebagai sumbangan pemikiran tentunya patut dipertimbangkan. Hanya, perlu merujuk pada kasus organisasi petani yang berpola gerakan rakyat. Fakih menggambarkan bahwa arus besar paradigma developmentalism turut membentuk karakter gerakan sosial (Fakih, 2000). Developmentalism menjadi landasan gerakan sosial. Hanya saja pada era 1970-an gerakan sosial berangkat dari upaya mencari alternatif/metode mengimplementasikan aspek metodologis dan teknis pembangunan tanpa pertanyaan kritik atas dasar filosofis pembangunan itu sendiri. Diskursus gerakan sosial dalam konteks pembangunan diramaikan oleh tulisan Korten (2001) yang menggarisbawahi masalah pembangunan yang dalam perspektif dialektis menunjukkan saling keterkaitan antara persoalan eksploitasi, dominasi dan penindasan politik. Masih dalam tulisan Korten, gerakan sosial diposisikan dalam upaya perjuangan transformasi yang menyangkut tiga persoalan dasar yakni masalah keadilan, kesinambungan sumber daya alam, dan partisipasi. Dengan demikian gerakan sosial menjadi prasyarat untuk melakukan transformasi hingga mencapai alternatif pembangunan berorientasi rakyat (people-centered development)

Dalam pandangan Harper (1989), terdapat tiga pendekatan yang dapat digunakan untuk menjawab pertanyaan: bagaimana dan mengapa muncul gerakan sosial dan kondisi apakah yang dapat merangsang gerakan sosial?. 


\section{Organisasi dalam konteks pembangunan}

Pengalaman pengorganisasian petani masa orde baru memperlihatkan konsep organisasi petani dimaknai oleh pemerintah dalam konteks pembangunan. Pembentukan organisasi petani pada masa ini lebih untuk menghubungkan kepentingan pemerintah dengan komunitas lokal. Dengan demikian organisasi di tingkat lokal seringkali hanya menjadi perpanjangan tangan pemerintah dalam menggulirkan agenda-agenda pembangunan yang bersifat top down. Dalam pembahasan yang agak berbeda, organisasi seringkali diarahkan pada sebuah organisasi bentukan pemerintah untuk merespon program-program pembangunan dari atas (Israel, 1990; Cernea, 1988). Program pembangunan yang diintroduksikan ke tingkat desa membawa serta ideologi baru tentang peran masyarakat lokal dalam proyek pembangunan. Alasan ini yang mendorong pemerintah membentuk organisasi petani untuk memfasilitasi pembangunan di tingkat desa.

Israel (1990) dalam tulisannya tentang program irigasi bank dunia memaparkan kelembagaan irigasi yang dibangun oleh pemerintah. Dalam pemaparannya, Israel mengemukakan bahwa organisasi di tingkat komunitas diperlukan pemerintah untuk mensosialisasikan proyek pembangunan. Senada dengan tulisan Cernea (1988) yang membahas terbentuknya organisasi di tingkat petani namun dengan pendekatan topdown. Dengan begitu, sampai tahun 1990-an organisasi petani yang ada merupakan perpanjangan tangan pemerintah dalam berbagai bidang misalnya pertanian dengan kelompok tani-nya, demikian juga kehutanan dengan KTH-nya.

Tulisan Tjondronegoro (1984) kemudian menunjukkan bahwa pembangunan dengan pendekatan dari atas hanya menegasikan keberadaan lembaga lokal. Ketika program masuk ke masyarakat, muncul organisasi bentukan pemerintah. Seperti yang dikemukakan di awal bahwa organisasi dengan ciri demikian tidak cukup efektif memenuhi kebutuhan di tingkat lokal. Organisasi bentukan lebih berorientasi pada kekuasaan dan pemerintah sehingga gagal menjadi bagian dari masyarakat. Penelitian Tjondronegoro (1984) berhasil menunjukkan bahwa di tingkat lokal ada relung sodality yang terbangun di tingkat dukuh. Sodality inilah yang kemudian menjadi solusi atas ketidakberhasilan pembangunan melalui organisasi melalui pendekatan alternatif kelembagaan.

Pandangan lain mencoba mengemukakan bahwa lembaga di tingkat lokal dan berangkat dari kebutuhan komunitas itu sendiri dapat menjadi alat bagi petani untuk mencapai tujuan tertentu dalam hubungannya dengan aktor luar. Hasil penelitian Firmansyah dkk (1999) membuktikan bahwa organisasi yang dibentuk oleh petani dapat lebih efektif dan efisien dalam membangun kekuatan petani di tingkat lokal. Keberhasilan dibuktikan melalui makin banyaknya organisasi petani yang tumbuh dan berhasil mencapai tujuan organisasinya.

\section{Kerangka Pemikiran}

Analisis perlawanan petani dalam pandangan Harper (1989) dapat dilakukan dengan menggunakan tiga pendekatan yaitu bagaimana, mengapa, dan dalam kondisi apakah sebuah organisasi ${ }^{3}$ bisa muncul. Konteks sosial yang memicu perlawanan harus dilihat secara holistik. Komunitas harus dipandang sebagai kompleks yang saling berinteraksi pada tiga tingkat, yaitu ekonomi, politik dan ideologi dimana kontradiksi berkembang di dalam maupun antar aras.

Jalinan aspek ekonomi, politik, dan ideologi harus dipahami sebagai basis pijakan menganalisis konteks sosial dibangunnya perlawanan melalui pembentukan organisasi petani. Alternatif memindahkan pola perlawanan - akibat pengaruh konteks sosial komunitas - dari radikal menuju perlawanan halus dan lebih berciri CD perlu melihat konfigurasi kekuasaan negara atas faktor ekonomi dan politik sebagai dasar analisis. Dengan kata lain, perlawanan petani yang berangkat dari persoalan spesifik melahirkan pendekatan organisasi yang khas pula. Pilihan atas bangunan organisasi pada akhirnya menjadi strategi lanjut dari organisasi untuk mengembangkan perlawanan.

Sebagai organisasi yang mempunyai tujuan memperkuat posisi petani dan memperjuangkan kedaulatan petani, karakter perlawanan harus mengarah pada perlawanan yang berkelanjutan. Dengan demikian dalam penelitian ini akan dikaji tentang penyebab dan kemunculan, tujuan, strategi \& aktivitas, jaringan yang dibangun serta implikasi terhadap persoalan yang dihadapi. Pendekatan pengembangan komunitas gaya petani menghasilkan kemandirian petani yang berbasis pada kebutuhan dan permasalahan nyata yang dirasakan petani. Dalam hal ini organisasi sebagai bentuk perlawanan yang bersifat politis masih memerlukan sudut pandang lain untuk memahami secara utuh. Ketika petani terlibat dalam persoalan struktural maka perlu diterapkan strategi lain agar perlawanan yang dikembangkan oleh komunitas yang bersangkutan tidak tampak dan tidak menimbulkan penolakan dari pihak yang dilawan. Penyamaran ini, dalam konteks Indonesia menjadi penting terkait ideologi pembangunan dengan segala doktrin modernis/developmentalis-nya.

Jika dikaitkan dengan pemaparan Korten (2001) dapat dikemukakan bahwa organisasi mengarah pada paradigma people-centered development dan merujuk pada upaya transformasi pembangunan. Dalam sumbangan pemikiran Korten, organisasi dengan karakter demikian dapat dikategorikan kedalam organisasi rakyat generasi keempat yang bicara tentang konsep atau ideologi strategi alternatif pembangunan dan melihat bahwa masalah dasar pembangunan tidak lagi berskala lokal/nasional, tetapi global.

\footnotetext{
3 Organisasi dapat didefinisikan sebagai manifestasi perlawanan petani. Melalui organisasi petani dapat melawan tekanan struktural yang muncul. Organisasi juga bisa dianggap sebagai perkembangan lanjut strategi perlawanan yang dikembangkan petani.
} 


\section{METODOLOGI PENELITIAN}

Fokus organisasi studi adalah Serikat Paguyuban Petani Qaryah Thayyibah (SPPQT) yang merupakan organisasi yang beranggotakan paguyuban petani di tiap kawasan yang masing-masingnya beranggotakan kelompok tani lokal. SPPQT mewakili sebuah bentuk organisasi yang dibangun atas permasalahan ekonomi yang dialami oleh anggotanya. Dengan kata lain, organisasi ini merupakan sebuah organisasi petani berbasis produksi.

Teori yang dibangun dalam memahami fenomena organisasi petani berangkat dari kesadaran bahwa realitas yang ada harus dipahami secara kritis. Pada ranah metodologis, penelitian ini menggunakan pendekatan kritis dengan menggunakan teknik interpretatif-kritis tanpa mengabaikan makna-makna dibalik respon petani atas permasalahan struktural yang dialami. Fenomena keberadaan organisasi petani diinterpretasikan secara kritis dari realitas sosial yang ada.

Strategi yang digunakan adalah studi kasus dimana tipe organisasi yaitu production based organization menjadi subyek penelitian. Studi kasus dilakukan dengan alasan penelitian tentang organisasi petani memerlukan gambaran utuh dalam menangkap fenomena organisasi petani yang telah banyak tumbuh di Indonesia. Yin (1996) mengemukakan bahwa studi kasus adalah studi aras mikro yang bersifat multimetode dengan titik berat pada metode-metode nonsurvei.

Gambaran realitas sosial dianalisis dengan menggunakan teori kritis dalam ranah interpretatifkritis. Dengan dukungan teoritis, secara kritis realitas sosial ditarik pada satu kesimpulan yang berupaya memahami makna dibalik realitas/fenomena sosial. Analisis kritis juga dikembangkan dengan melibatkan proses dialogis-komunikatif. Proses dialogiskomunikatif mutlak diperlukan dalam paradigma kritis karena secara filosofis realitas sosial tidak hakiki melainkan hasil interpretasi individu yang bersifat relatif-subyektif terkait dengan pengalaman individu.

\section{Latar Belakang Terbentuknya Organisasi}

Faktor yang menyebabkan ketertindasan petani adalah ekonomi dan politik. Dua faktor ini dalam sejarahnya menciptakan deretan permasalahan yang harus diselesaikan oleh petani. Disisi lain, keberadaan dua faktor ini ternyata mampu memunculkan motivasi petani untuk membangun aksi kolektif dan mengakumulasikan energi kolektif melalui pembentukan organisasi. Permasalahan petani yang lebih banyak meliputi ekonomi menuntut bentuk organisasi yang dapat mengakomodir kebutuhan tersebut. Muatan respon atas pola relasi yang eksploitatif harus dikompromikan dengan kebutuhan yang bersifat praktis. Ciri organisasi produksi yang lebih mengarah pada paradigma production-center oriented merupakan respon organisasi atas permasalahan nyata petani.
Alasan organisasi mengembangkan strategi CD menyangkut pertimbangan karakter petani dan juga karakter musuh. Bacaan awal terhadap bentuk musuh menghasilkan analisis bahwa organisasi petani harus dibangun dalam bentuk yang terorganisir dengan baik. Alasan pilihan tersebut disandarkan pada dua hal, yaitu: pertama, yang paling penting dalam organisasi adalah memperkuat daya resistensi petani, bukan dengan caracara seperti reklaiming. Kedua, pilihan radikal lebih rawan perlawanan/resistensi dari pemerintah. Pertimbangan atas dua alasan di atas kemudian menghasilkan organisasi dengan ciri yang terstruktur.

Peranan faktor ekonomi dan politik sebagai pendorong gerakan pengorganisasian menarik untuk dipahami terutama dalam hal pengaruhnya terhadap kehidupan petani. Penelusuran periodisasi konteks ekonomi berhasil menunjukkan bahwa pada setiap fase, petani tidak pernah didudukkan dalam tempat yang benar dalam struktur masyarakat. Revolusi hijau merupakan kebijakan pertanian yang dampaknya paling nyata dirasakan petani, terutama bagi petani miskin dan buruh tani. Terciptanya kesenjangan makin menempatkan dua golongan petani ini kedalam struktur paling bawah dalam kelas sosial. Gambaran bahwa revolusi hijau membatasi akses masyarakat miskin makin tampak ketika paket-paket teknologi pertanian yang ditawarkan hanya dimungkinkan menjangkau golongan petani kaya. Petani menjadi sandaran kebijakan pembangunan sekaligus korban pembangunan yang dikembangkan. Itulah sebabnya mengapa ketika krisis ekonomi muncul pada tahun 1998, petani sebagai golongan masyarakat yang paling marjinal berupaya "menarik keuntungan" dari keterpurukan bangsa.

Keterkaitan dengan konteks ekonomi global dapat dilihat dalam kasus pemberlakuan kebijakan pasar bebas dan globalisasi. Pemerintah tanpa perhitungan terseret dalam arus kapitalisme sehingga persaingan global makin menyudutkan langkah petani. Relasi sosial yang mengemuka antara negara, modal dan kaum tani diungkapkan oleh Fauzi (1998) terbukti menghegemoni kekuatan petani terlebih ketika Indonesia turut dalam arus kapitalisme global.

Pengalaman pengorganisasian petani juga menunjukkan bahwa konteks politik turut memicu lahirnya organisasi. Reformasi politik pada tahun 1998 membawa momentum formasi pada banyak organisasi petani di berbagai aras. Era ini juga membawa serta berbagai implikasi struktural dalam kancah perpolitikan di Indonesia. Perjalanan politik masa ke masa menunjukkan perjalanan yang hampir senada dengan perjalanan ekonomi. Pada masa Soeharto, pemerintah melakukan tekanan yang sangat kuat terhadap munculnya organisasi rakyat. Tindakan ini menghambat perjuangan tingkat grass root yang seringkali dilakukan dengan organisasi. Banyak organisasi yang dibentuk di tingkat lokal dianggap sebagai bentuk perlawanan terhadap negara. Gerakan yang relatif tidak mendapat hambatan dari pemerintah adalah gerakan yang bersifat kultural. Dalam sejarah organisasi SPPQT, gerakan 
kultural ini ternyata sampai pada gerakan yang mensikapi persoalan struktural yang dialami petani.

Peran organisasi kultural yang dimaksud di atas adalah gerakan NU. NU yang dalam perkembangannya menunjukkan bentuk transformasi gerakan memberi ruang yang cukup kepada kadernya untuk mengembangkan pengorganisasian. Hal ini tidak lepas dari peran NU senior dengan pemikiran-pemikiran yang progresif. Persentuhan inisiator organisasi dengan tokoh NU progresif melahirkan kelompok tani sebagai embrio SPPQT.

Kelanjutan gerakan rakyat mendapat ruang yang lebih luas ketika suasana gerakan kerakyatan mulai menguat. Bisa dikatakan bahwa tahun 1998 merupakan titik balik gerakan rakyat di Indonesia. Perjuangan petani pasca 1998 tidak lagi dilakukan dengan cara sembunyi-sembunyi. Ideologi perlawanan terhadap perangkat keras dan perangkat lunak yang merugikan petani mulai ditransformasikan ke tingkat petani. Maka mulailah ditemukan organisasi rakyat/organisasi komunitas di pelosok pedesaan. Sebagai wadah memenuhi kebutuhan kolektif, organisasi kemudian berkembang dan menjadi multifungsi sesuai kebutuhan anggotanya.

Mengingat pentingnya menempatkan kebutuhan anggota sebagai dasar bangunan organisasi, SPPQT memilih kegiatan yang dapat menjawab kebutuhan anggota. Alasan ini mendorong pilihan pola organisasi yang lebih halus tanpa menghancurkan struktur sosial yang telah mapan. Pilihan ini tidak lepas dari sejarah terbentuknya SPPQT serta embrio kelompok tani. SPPQT hendak memaknai organisasi dalam kerangka pengembangan petani, tidak sekedar pengembangan pertanian. Pemaknaan ini diimplementasikan dalam bentuk organisasi produksi meski dalam perkembangannya, SPPQT juga menempuh cara-cara advokasi untuk merespon persoalan agraria. Keduanya merupakan strategi untuk sampai pada akses dan kontrol atas sumberdaya.

\section{Selayang Pandang Organisasi Petani SPPQT}

Konteks sosial yang dialami oleh petani yang berada di kawasan ekologis tertentu tidak terlepas dari belitan persoalan yang menghimpit petani terutama terkait dengan kepentingan meningkatkan derajat kesejahteraan keluarga petani. Disadari oleh petani bahwa kelompok petani yang bersifat lokal kurang mampu mengakomodir kepentingan yang bersifat global. Oleh karenanya, ada ide besar untuk menyatukan perjuangan dalam wadah yang lebih luas. Dengan pertimbangan tersebut, maka dibentuklah sebuah serikat petani yang merupakan gabungan beberapa paguyuban petani di tingkat kawasan. Beberapa paguyuban petani berinisiatif membentuk serikat petani yang kemudian dikenal dengan Serikat Paguyuban Petani Qoryah Thoyibah (SPPQT).

SPPQT merupakan sebuah organisasi petani yang beranggotakan paguyuban yang menyebar pada kawasan-kawasan di Kendal, Magelang, Sragen, Salatiga, Semarang, Boyolali, dan Temanggung.
Konteks berdirinya kelompok tani di masing-masing kawasan tidak lepas dari persoalan yang dihadapi oleh petani setempat. Sebagian besar paguyuban dan kelompok berada pada daerah dataran tinggi. Daerah dataran tinggi merupakan daerah dengan kondisi ekologi yang unik serta kondisi sosial ekonomi yang khas. Antara keduanya memiliki hubungan yang erat dimana kondisi sosial ekonomi masyarakat dataran tinggi dibentuk oleh kondisi ekologis. Keberadaan wilayah dataran tinggi seringkali identik dengan jauhnya komunitas dari sumber informasi dan akses transportasi. Tidak mengherankan apabila kondisi sosial ekonomi masyarakat relatif lebih rendah dibanding masyarakat yang berada di dataran rendah.

Permasalahan utama yang dihadapi petani bergerak diseputar isu-isu pertanian dari mulai masalah pengadaan sarana produksi dan alat produksi, masalah teknik budidaya, masalah penanganan pasca panen, masalah pengolahan hasil dan pemasaran. Beberapa permasalahan tersebut sebagian atau seluruhnya hampir dapat ditemui di tingkat petani. Diantara masalahmasalah tersebut, masalah pemasaran merupakan masalah utama. Permasalahan pemasaran selalu berujung pada masalah harga yang rendah di tingkat petani.

Ketiadaan lembaga pendukung kegiatan pertanian yang kurang menyentuh lapisan petani, menjadi faktor penyebab timbulnya masalah-masalah tersebut. Lembaga tersebut dapat berada pada ranah formal maupun informal. Dalam banyak kasus, kelompok tani difasilitasi oleh lembaga pendukung formal. Kegiatan yang difasilitasi oleh lembaga formal seringkali hanya memanfaatkan kelompok yang secara struktural berada di bawah pemerintah seperti kelompok tani. Keberadaan kelompok tadi didukung oleh kehadiran lembaga-lembaga seperti; Potugas Penyuluh Lapang (PPL), Dinas Pertanian, perusahaan-perusahaan dan Pemerintah Daerah. Sangat disayangkan bahwa peran-peran lembaga tadi dirasa kurang berarti dilihat dari sudut menciptakan inisiatif tingkat lokal karena petani selama ini hanya menjadi penerima inovasi. Demikian pula ketika petani dihadapkan pada jalur distribusi yang lebih sering dijegal oleh tengkulak ataupun free rider baik dalam tingkat harga maupun konsumen.

295 | Sokoasri, Valentina. et al. Dampak Reforma Agraria dari Bawah terhadap Kesejahteraan Masyarakat di Desa Garongan Daerah Istimewa Yogyakarta 
Secara struktural petani diciptakan menjadi golongan yang tidak mampu bangkit. Petani menjadi pihak yang lemah dan kurang diperhatikan. Kondisi demikian diperparah oleh adanya kenyataan bahwa petani memiliki sifat yang cair sehingga seringkali sulit disatukan dalam perjuangan meningkatkan kesejahteraan. Masing-masing petani bekerja atas kepentingan sendiri dan sulit ditemukan bentuk organisasi antar mereka. Kalaupun pernah dibentuk organisasi tani, lebih pada wujud representasi penguasa di tingkat lokal masyarakat desa. Organisasi tani seperti KTNA, Poktan, dan KTH merupakan organisasi petani yang ada di tingkat desa. Organisasi ini dalam persepsi petani dikenal dengan organisasi bentukan pemerintah. Akan tetapi bukan organisasi seperti ini yang dikehendaki oleh petani. Organisasi tani yang diharapkan petani adalah yang mampu menampung aspirasi kepentingan petani, mampu melibatkan petani dalam setiap pengambilan keputusan dan mampu memberi akses seluas-luasnya baik informasi maupun teknologi. Jadi organisasi tani yang dibutuhkan adalah yang berasal dari masyarakat petani sendiri dan dalam proses pembentukan melibatkan semua anggotanya mulai dari awal hingga akhir.

Dengan demikian, tampak bahwa latar belakang pendirian SPPQT diantaranya adalah: pertama, persoalan yang dihadapi petani yang semakin sempit dalam mengakses dan mengontrol sumberdaya tanah dan kepemilikan tanah. Tercatat rata-rata kepemilikan tanah sekitar $2000 \mathrm{~m}^{2}$ dengan kondisi rusak. Kedua, kepemilikan sumber daya air menjadi milik pemodal (privatisasi) yang sebelumnya milik publik. Ketiga, ketergantungan petani terhadap benih, pupuk, bibit, dan obat-obatan sebagai akibat revolusi hijau. Program ini menimbulkan pergeseran budaya petani. Keempat, lemahnya kelembagaan ekonomi petani. Kelima, biaya pendidikan yang mahal bagi anakanak petani. Keenam, sulitnya akses kesehatan. Ketujuh, peraturan/kebijakan pemerintah yang tidak memihak keluarga petani. Kedelapan, tekanan penguasa selama 32 tahun menciptakan budaya petani, terutama menurunnya tingkat kepercayaan pada kemampuannya, keengganan berkumpul dengan sesama petani, dan kecenderungan sikap individual.

\section{Karakter Organisasi}

Organisasi petani yang relatif tersistematis baru muncul di era reformasi. ${ }^{4}$ Tumbuhnya organisasi di Salatiga berangkat dari fakta tentang permasalahan seputar isu produksi dan pemberdayaan. Dalam hal ini serikat memiliki peran yang besar dalam menumbuhkan terbentuknya organisasi. Peran tersebut terutama dalam hal pembentukan, penyediaan fasilitas, pembinaan, dan membangun jaringan. Embrio kelompok anggota SPPQT telah ada sebelumnya dalam bentuk kelompokkelompok tani bentukan pemerintah maupun organisasi lokal komunitas setempat.

\footnotetext{
${ }^{4}$ Dari penelitian awal terungkap bahwa banyak gerakan yang dimulai jauh sebelum era reformasi namun belum sampai pada pengorganisasian. Organisasi petani pertama kali tumbuh adalah BTI.
}

Tabel 3. Perbedaan Ciri Organisasi Anggota Serikat Sebelum dan Sesudah Tahun 1998

\begin{tabular}{|c|c|c|}
\hline $\begin{array}{l}\text { Analisis Pembeda } \\
\text { Organisasi }\end{array}$ & Sebelum 1998 & Sesudah 1998 \\
\hline Inisiatif & $\begin{array}{l}\text { Pemerintah/kom } \\
\text { unitas lokal }\end{array}$ & $\begin{array}{l}\text { Komunitas lokal } \\
\text { dibantu oleh } \\
\text { Serikat }\end{array}$ \\
\hline Cakupan kegiatan & $\begin{array}{l}\text { Keagamaan, } \\
\text { sosial } \\
\text { kemasyarakatan }\end{array}$ & $\begin{array}{l}\text { Pertanian, dan } \\
\text { upaya menjawab } \\
\text { permasalahan } \\
\text { petani }\end{array}$ \\
\hline Tujuan organisasi & $\begin{array}{l}\text { Membangun } \\
\text { kebersamaan }\end{array}$ & $\begin{array}{l}\text { Membangun } \\
\text { kemandirian }\end{array}$ \\
\hline Respon atas & $\begin{array}{l}\text { Permasalahan } \\
\text { sosial }\end{array}$ & $\begin{array}{l}\text { Permasalahan } \\
\text { petani secara } \\
\text { umum }\end{array}$ \\
\hline $\begin{array}{l}\text { Model pendekatan } \\
\text { pembentukan }\end{array}$ & $\begin{array}{l}\text { Bentukan } \\
\text { pemerintah, } \\
\text { bagian dari } \\
\text { pemerintahan }\end{array}$ & $\begin{array}{l}\text { Inisiatif lokal yang } \\
\text { didorong serikat }\end{array}$ \\
\hline
\end{tabular}

Model pendekatan diwadahi dalam kegiatankegiatan yang mengartikulasikan kebutuhan petani baik jangka pendek maupun jangka panjang. Pendekatan ini dianggap sebagai bagian dari pembagian kerja organisasi. Pembagian kerja manajemen organisasi menjadi modal untuk lebih mengarahkan petani pada tujuan strategis. Disamping itu, seluruh kegiatan diarahkan pada pencapaian kemandirian petani. Kemandirian ini merupakan ciri organisasi yang berasal dari komunitas dan muncul setelah tahun 1998. Tentunya berbeda dengan ciri organisasi sebelum tahun 1998. Perbedaan ciri organisasi sebelum 1998 dan sesudah 1998 ditampilkan dalam Tabel 3.

Sebagai sebuah organisasi yang memperjuangkan kedaulatan petani, SPPQT dan anggotanya menerapkan strategi yang lebih mengarah pada pemberdayaan petani dan fokus pada aktivitas ekonomi. Karakter SPPQT secara umum adalah: pertama, berupaya memutus ketergantungan pada pemerintah dalam hal penyediaan sarana produksi pertanian dengan cara melakukan kegiatan pertanian organik yang disamping bertujuan memutus hubungan dengan pemerintah juga untuk membangun kemandirian petani. Kedua, struktur organisasi dibentuk secara rapi dan sistematis dimaksudkan untuk memudahkan jalur koordinasi. Ketiga, memperkuat struktur organisasi supaya memiliki bargaining position dan bargaining power dihadapan pengambil keputusan. Keempat, kemandirian petani yang menjadi tujuan pokok organisasi diwujudkan dalam bentuk melakukan pembinaan berjenjang pada satu tingkat di bawahnya.

Untuk sampai pada karakter di atas, kegiatan organisasi banyak diarahkan pada kegiatan pertanian dan pengembangan petani. Aspek pertanian menjadi fokus utama kegiatan pertanian. Tidak mengherankan jika dikaitkan dengan faktor pendorong terbentuknya organisasi petani yang banyak diilhami oleh persoalan ekonomi dan politik. Kegiatan pertanian menjadi agenda penting mengingat petani merupakan 
keanggotaan terbesar dari organisasi. Bidang-bidang kegiatan yang dikembangkan oleh organisasi meliputi kegiatan ekonomi produksi, kegiatan pendidikan, dan kegiatan berciri aksi-advokasi.

Dalam hal ini pilihan strategi yang diambil oleh SPPQT terkait dengan embrio SPPQT. Dalam banyak hal, SPPQT memperlihatkan bentuk-bentuk kooperatif dengan pemerintah. Ini agak berbeda dengan asumsi organisasi sebagai gerakan sosial yang cenderung menghindari kerjasama dengan pemerintah.

Embrio SPPQT adalah kelompok simpan pinjam yang telah berdiri sejak Tahun 1980-an. Merujuk pada tipologi yang dikemukakan Eldridge (1989) tentang karakter NGO, tampaknya NGO yang mendampingi kelompok simpan pinjam adalah kelompok yang menerapkan kerja-kerja pengorganisasian sekaligus pemberdayaan masyarakat. Itulah sebabnya, pilihan bentuk kelompok adalah kelompok dengan mengembangkan kegiatan ekonomi.

Tampak bahwa Tahun 1999 merupakan waktu dimana terjadi perubahan bentuk organisasi. Tahun 1999 merupakan tahun dimana bentuk SPPQT lebih sistematis dan mengambil bentuk organisasi modern. Pertimbangan bentuk organisasi demikian adalah adaptasi terhadap tujuan organisasi yang mengarah pada organisasi petani yang kuat dan melakukan akses dan kontrol terhadap sumberdaya yang ada. Berbeda dengan bentuk embrio SPPQT yang masih berciri informal. Sejajar dengan analisis yang dikemukakan Eldridge (1989), SPPQT pada masa ini menunjukkan karakter lembaga dengan tujuan penguatan dan mobilisasi akar rumput. Namun tujuan tersebut ditempuh dengan pendekatan pembangunan akar rumput. Dua hal di atas berbeda ranah mengingat penguatan dan mobilisasi akar rumput berorientasi pada gerakan sedangkan pembangunan akar rumput lebih berorientasi pada kerjasama.

Dalam perkembangannya, meskipun dominan oleh kegiatan ekonomi, namun kegiatan ekonomi yang dilakukan tidak lepas dari kaitan gerakan perlawanan. Sebagai contoh, kegiatan ekonomi produksi yang dikembangkan adalah Integrated Organic Farming (IOF) yang dimaknai sebagai proses pertanian yang terintegrasi, tidak terbatas pada pertanian organik. Petani diharapkan mampu memanfaatkan sumberdaya lokal yang ada, sekaligus tanggap terhadap persoalan agraria yang ada. Masalah kepemilikan tanah menjadi fokus perhatian. IOF tidak mengharapkan petani kaya menyewa lahan dari petani miskin. Kegiatan pendidikan juga dimaknai sebagai respon terhadap kapitalisasi pendidikan yang terjadi. Model pembelajaran yang dikembangkan adalah pola pendidikan pembebasan (Freire, 1984) dimana peserta dibebaskan menggali ilmu dari alam sekitar yang menjadi laboratorium pendidikan. Kasus TNMM disikapi dengan membuat draf yang bernuansa akademis sebagai draf tandingan atas status TNMM.

\section{People-Center Oriented Sebagai Agenda Utama Organisasi}

Sebagai turunan dari paradigma modernisasi, pendekatan pengorganisasian pada organisasi yang memilih pendekatan $\mathrm{CD}$ menunjukkan karakter yang dekat dengan ciri-ciri modernisasi yang dibawa oleh teori besarnya. Kesamaan karakter terutama ditunjukkan melalui jalur-jalur pendekatan yang dipergunakan untuk memberdayakan masyarakat. Bentuk organisasi dengan menggunakan pendekatan $\mathrm{CD}$ versi baru mengarah pada karakter organisasi dalam bentuk organisasi komunitas dan sedang dalam proses menuju organisasi politik. Tampak dari kegiatan yang berbasis lokal sebagai ciri khas organisasi komunitas. Proses mengarah pada organisasi politik diperlihatkan ketika anggota kelompok tani/paguyuban melibatkan diri dalam konstelasi politik lokal. Keterlibatan petani dalam konstelasi politik tingkat lokal dan nasional merupakan perkembangan lanjut membangun posisi tawar petani.

Bentuk organisasi gaya CD ditinjau dari sudut perlawanan memerlukan justifikasi tersendiri. Tidak dapat dipungkiri bahwa terminologi $\mathrm{CD}$ merupakan jargon pemerintah orde baru. Meski makna yang muncul pada masa orde baru lebih mengarah pada upaya "pemaksaan" ideologi, namun CD yang muncul kemudian memiliki sifat yang berbeda. Pendekatan pemberdayaan petani dalam mencapai akses dan kontrol dilakukan dengan strategi CD yang sekaligus digunakan untuk menjaga keberlangsungan perlawanan. Dalam tahap-tahap tertentu dapat dikatakan bahwa SPPQT belum mencapai separuh dari target awal perlawanan. Terutama ketika dikaitkan dengan transformasi gerakan yang harus sampai pada tingkat paguyuban dan kelompok. Program yang dikembangkan SPPQT belum sampai pada kesadaran bahwa program tersebut berangkat dari nilai-nilai gerakan tertentu. Tapi bahwa program tersebut dianggap sebagai tahap awal membangun gerakan patut mendapat perhatian tersendiri.

Kondisi yang memaksa petani mengorganisir diri telah dibahas dengan lengkap pada bab 1. Namun demikian, persambungan akan tetap dijumpai dalam bab ini. Kerangka ideologi pembangunan yang telah berkembang memaksa petani ditempatkan dalam posisi sebagai obyek pembangunan tanpa dilibatkan dalam proses perencanaan maupun pengambilan keputusan. Mainstream pembangunan pertanian menghasilkan paradigma production-center oriented yang menghasilkan kondisi dimana petani mengalami ketergantungan pada struktur elit dan program, adanya dominasi elit serta upaya mengintegrasikan petani menuju kapitalis. Pembangunan pertanian dengan paradigma di atas hanya merespon permasalahan petani secara parsial. Salah satunya adalah ketika revolusi diterapkan di Indonesia. Program revolusi hijau yang sejatinya dimaksudkan membantu ketersediaan pangan justru menimbulkan masalah di kalangan masyarakat pedesaan

Gerakan rakyat kemudian mencoba merespon kondisi tersebut dengan membangun kelembagaan yang kemudian dikenal dalam bentuk organisasi petani. Organisasi petani sebagai organisasi yang mengarah

297 | Sokoasri, Valentina. et al. Dampak Reforma Agraria dari Bawah terhadap Kesejahteraan Masyarakat di Desa Garongan Daerah Istimewa Yogyakarta 
pada upaya pemberdayaan memainkan peran sebagai wadah untuk mencapai cita-cita petani yaitu kemandirian dan kedaulatan petani atas sumberdayanya. Organisasi sebagai kritik atas paradigma pembangunan pertanian kemudian menerapkan paradigma baru yang lebih menempatkan manusia sebagai subyek pembangunan (Gambar 7.) tanpa meninggalkan agenda gerakan sosial petani.

Pilihan atas paradigma pembangunan pertanian yang berorientasi people-center development memaksa orang di luar organisasi untuk memahami alasan di balik pilihan tersebut. Dari sekian permasalahan yang dihadapi petani, pendekatan people-center oriented diharapkan menjadi instrumen bagi tercapainya kedaulatan petani. Paradigma people-center oriented pada prakteknya memerlukan strategi untuk menghindari resistensi pemerintah. Untuk menghindari hal tersebut, organisasi mengembangkan kerjasama dengan pemerintah dan mengembangkan strategi $C D$ sebagai sebuah pendekatan yang dapat diterima di mata pemerintah. Melalui strategi tersebut terbukti organisasi petani mampu memperjuangkan kedaulatan petani, membangun kemandirian melalui pembentukan organisasi petani dan mengembangkan perlawanan terhadap production-center development dengan mengubah menjadi people-center oriented tapi dengan strategi pendekatan production-center oriented.

People-center oriented yang sedang diperjuangkan merupakan kritik atas pembangunan yang berorientasi pada production-center development. Pengorganisasian yang diterapkan oleh organisasi petani berangkat dari prinsip-prinsip perlawanan dalam kerangka gerakan yang dibungkus dengan pendekatan production-center oriented. Melawan dilakukan di bawah payung slogan-slogan pembangunan pemerintah sambil mendefinisikan kembali slogan tersebut kedalam pengertian paradigma yang lebih berorientasi pada people-center oriented.

\section{Strategi perlawanan}

Rubin and Rubin (2001) menggarisbawahi kontinuum lanjut dari bergabungnya banyak aktor dan banyak organisasi dalam melawan ketidakadilan dan ketimpangan akan melahirkan agenda gerakan sosial. Konsekuensi lanjut dari kontinuum tersebut adalah gagasan alternatif yang menggabungkan kepentingan ekonomi dengan analisis relasi sosial. Dalam hal ini, menjadi penting untuk melakukan analisis silang antara pendekatan modernisasi dengan kerangka Marxian yang kental konflik kelas dan penyadaran. Pada satu titik ada peluang bahwa organisasi komunitas dibangun dengan menggunakan variabel-variabel pembangunan namun dengan target kedaulatan petani dalam konteks perlawanan atas ketertindasan/ketimpangan yang menjadi point penting paradigma Marxian.

Pemikiran neo-Marxian dalam hal ini ditempatkan pada posisi mengkaji faktor-faktor yang saling berkaitan dalam struktur masyarakat. Persoalan yang dihadapi petani adalah persoalan struktural yang harus dilihat dari integrasi tiga faktor yakni ekonomi, politik, dan ideologi. Dengan demikian, meminjam kerangka yang dikemukakan aliran ini, akan tampak bahwa persoalan yang dihadapi masyarakat bersifat kompleks dan harus direspon dengan strategi yang integral dan holistik.

Kontekstual masalah memerlukan respon yang tepat di tingkat petani. Analisis relasi kekuasaan yang tercipta di masyarakat memerlukan pendekatanpendekatan yang inovatif. Langkah ini terutama diperlukan untuk menghindari perlawanan yang lebih kuat dari perangkat keras dan perangkat lunak yang memarjinalkan petani. Meski dikemukakan bahwa musuh petani pada era setelah 1998 dinilai abstrak, namun kekuatan yang berada dibalik persoalan tersebut sangat kuat. Kondisi demikian memerlukan pertimbangan khusus tentang cara-cara perlawanan yang efektif.

Secara teoritis perlawanan dapat dilakukan dengan cara yang halus, tanpa mengubah struktur yang ada, atau dengan cara dekonstruksi sosial. Perlawanan yang mempertahankan kemapanan dalam terminologi Scott (1993) dikenal dengan perlawanan tersembunyi, atau perlawanan dalam kepatuhan menurut Heryanto (2000). Sedangkan perlawanan dengan cara dekonstruksi dilakukan dengan merombak struktur yang ada. Pola perlawanan yang dikembangkan oleh organisasi petani SPPQT tidak dilakukan dengan mengubah struktur yang ada, melainkan mempergunakan struktur yang ada dan menjadi bagian dari sistem tersebut untuk kemudian memperbaiki sistem dari dalam. Perlawanan dilakukan terhadap kemapanan yang ada dengan cara memperkuat aliansi dan menjadi bagian dari agenda negara. Isu pokok yang ditawarkan organisasi menjadikan gerakan ini tidak eksklusif, namun tetap dalam kerangka perlawanan yang diarahkan keluar dari mainstream umum yang berkembang.

Disain perlawanan SPPQT dan organisasi yang ada di bawahnya adalah bentuk perlawanan tersembunyi melalui strategi kemandirian produksi. Perlawanan tersamar merupakan proses adaptasi terhadap kemapanan sosial yang sedang berlangsung. Dalam hal ini petani harus mau "membunglon" untuk menghindari resistensi pemerintah. Meski diawal pembentukan, organisasi memilih disain $\mathrm{CD}$, namun dalam perkembangannya organisasi ini menemukan dasar mendobrak kekuatan dengan cara memindahkan jalur perlawanan dari pola radikal ke pola yang lebih halus, dari production-center oriented menuju people-center oriented.

Perlawanan tersamar tidak berangkat dari asumsi agenda tersamar. Sebaliknya, agenda SPPQT bersifat terbuka dan dapat diterima oleh semua pihak. SPPQT menerapkan strategi perlawanan tersamar dalam tujuannya menghindari menguatnya resistensi pemerintah. Perlawanan yang dibangun oleh SPPQT tidak dilakukan dengan menciptakan struktur baru yang paralel dengan sistem yang ada melainkan mencari cara agar gerakan bisa diterima oleh pemerintah. Hal yang diperjuangkan yakni akses dan kontrol sejatinya juga 
diperjuangkan oleh seluruh lapisan masyarakat. Namun SPPQT membungkusnya dengan sesuatu yang dapat diterima bagi rezim yang berkuasa. Dapat dikemukakan di sini bahwa SPPQT mengembangkan perlawanan terhadap kemapanan yang ada dengan upaya mengintegrasikan petani kedalam sistem yang ada tanpa meninggalkan upaya memperjuangkan kedaulatan petani.

Perlawanan tersamar dipilih sebagai terminologi untuk memperlihatkan bahwa musuh (pemerintah) sebetulnya mengetahui tindakan petani. Namun musuh tidak bereaksi karena perlawanan dilakukan dengan pola-pola yang biasa dilakukan oleh pemerintah. Strategi community development menjadi berbeda ketika ditangani oleh komunitas. Perbedaan terutama terletak pada hasil akhir dan implikasi yang ditimbulkan. CD gaya lama lebih sebagai upaya mempertahankan kemapanan dan menciptakan ketergantungan petani, sedangkan $\mathrm{CD}$ gaya petani merupakan upaya menciptakan kemandirian dan mencapai kedaulatan petani.

Sebagai implikasi dari perlawanan dengan menerapkan strategi community development, SPPQT bersifat terbuka dalam menerima lembaga baru yang berniat membangun jaringan. Hal tersebut tidak lepas dari tujuan organisasi yang memerlukan banyak dukungan. Disamping itu, organisasi memiliki bentuk tegas dengan struktur jelas. Jenjang pembinaan organisasi relatif tertata sehingga orang luar lebih cepat memahami mekanisme yang ada dalam organisasi tipe ini.

\section{Daftar Pustaka}

Cernea, Michael M. 1988. Mengutamakan Manusia dalam Pembangunan: Variabel-variabel Sosiologi di dalam Pembangunan Pedesaan. UI Press. Jakarta

Fakih, Mansour. 2000. Masyarakat Sipil untuk Transformasi Sosial: Pergolakan Ideologi LSM Indonesia. Pustaka Pelajar. Yogyakarta

Fauzi, Noer. 1998. Dari Aksi Protes Petani Menuju Embrio Organisasi Massa Petani dalam Perlawanan Kaum Tani: Analisis Terhadap Gerakan Petani di Indonesia Sepanjang Orde Baru. Yayasan Sintesa dan Serikat Petani Sumatera Utara (SPSU). Medan

Fauzi, Noer. 2005. Memahami Gerakan-Gerakan Rakyat Dunia Ketiga. Insist Press. Yogyakarta

Firmansyah, dkk. 1999. Gerakan dan Pertumbuhan Organisasi Petani di Indonesia: Studi Kasus Gerakan Petani Era 1980-an. YAPPIKA dan Bina Desa. Jakarta

Friedmann, J. 1992. Empowerment: the Politics of Alternative Development. Blackwell Publishers. USA

Harper, C. L. 1989. Exploring Sosial Change. New Jersey: Prentice Hall. Hal 125-143
Heryanto, Ariel. 2000. Perlawanan dalam Kepatuhan.: Esai-esai Budaya. Mizan. Bandung

Hickey, Sam and Giles Mohan. 2005. Relocating Participation Within a Radical Politics of Development. Development and Change. Institute of Social Studies. Blackwell Publishing. Oxford. USA

Israel, Arturo. 1992. Pengembangan Kelembagaan: Pengalaman Proyek-Proyek Bank Dunia. LP3ES. Jakarta

Korten, David C. 2001. Menuju Abad ke-21: Tindakan Sukarela dan Agenda Global. Yayasan Obor Indonesia. Jakarta

Migdal, Joel. 1974. Peasants, Politics, and Revolution: Pressure Toward Political and Social Change the Third World. Princeton University Press. London

Pearse, Andrew. 1968. "Metropolis and Peasant: The Expansion of the Urban. Industrial Complex and the Changing Rural Structure dalam Teodor Shanin, Peasant and Peasant Societies (Teodor Shanin, ed; 1971). Penguin Books. Australia

Popkin. Samuel. 1986. Petani Rasional. Yayasan Padamu Negeri. Jakarta

Rubin and Rubin. 2001. Community Organizing and Development. A Pearson Education Company. Massachusetts

Scott, James. 1993. Perlawanan Kaum Tani. Terj. Yayasan Obor Indonesia. Jakarta

Soetomo, Greg. 1997. Kekalahan Manusia Petani: Dimensi Manusia dalam Pembangunan Pertanian. Pengantar: Dr. Ir. Wiryono. Kanisius. Yogyakarta

Sztompka, Piotr. 1994. The Sociology of Social Change. Blackwell Publishers

Tjondronegoro, S.M.P. 1984. Social Organization and Planned Development in Rural Java. Oxford University Press. Singapore

Yin, Robert K. 1996. Studi Kasus: Desain dan Metode. Jakarta: Raja Grafindo Persada 